ROCZNIKI PEDAGOGICZNE

Tom 13(49), numer $2-2021$

DOI: https://doi.org/10.18290/rped21132.8

HANNA SHACHAR

IRIT PEDRO

LIAT COHEN

\title{
THE VALUE OF FORGIVENESS \\ IN THE EYES OF HIGH-SCHOOL TEACHERS: \\ DO THEY PERCEIVE IT AS RELATED TO TESTING AND GRADING STUDENTS?
}

The educational system is an unforgiving system in that it assesses all students according to given criteria by using standardized tests. Those tests may be uniform exams conducted in a classroom by, say, math teachers, or national and international tests conducted by international organizations such as the OECD. Because of what I call its unforgiving nature, serious questions, and much criticism, have been raised over the last two decades by researchers and educators in the context of standardized testing and the damage it inflicts on students, teachers and schools (Berliner, 2011, 2015; Dieter-Meyer, 2014; Hargreaves, 2020; Heckman, Humphries, \& Kauts, 2014; Nichols, Berliner, \& Noddings, 2007; Jones, 2007; Ravitch, 2016; Sahlberg et al., 2017; Stone, 2016; Madaus \& Russell, 2017). The claim that educational systems are unforgiving as they test children that are utterly different from each other with uniform exams, is a matter that needs to be examined.

HANNA SHACHAR, PhD, Professor-Gordon College of Education, Bar Ilan University, Haifa, Izrael; e-mail: hannashachar@gmail.com; ORCID: https://orcid.org/0000-0003-4372-0270.

IRIT PEDRO, MeD—Gordon College of Education, Haifa, Izrael; e-mail: Iritpedro@gmail.com.

LiAT COHEN, MeD—Gordon College of Education, Haifa, Izrael; e-mail: Liat.cohen74@gmail.com. 


\section{FORGIVENESS AND TESTING}

Testing students in order to know how much they remember and understand from what they learned in school has been perceived as a central function of educational systems for the last two centuries. Yet the issue of forgiveness was never ascribed to the testing of children. Forgiveness was commonly addressed and discussed in religious and theological contexts (Halstead \& Taylor, 1996, p. 34; Etherington, 2013), and although in the last four decades the issue has also been dealt with by psychologists and social science researchers (McCullough et al.,1998; Toussaint \& Webb, 2005; McNulty, 2020) one might still doubt its connection to education. To address that doubt, a definition of the term forgiveness is needed. According to Denham and her colleagues (2005) forgiveness is:

Transformation of one's affect, cognitive judgments, and motivations toward an offender. The victim makes an assessment of the harm done and acknowledges the perpetrator's responsibility but voluntarily chooses to giving up the need for revenge, punishments, or restitution. One removes oneself from the negative emotions directly related to the transgression. Over time, there is a reduction in negative motivations and an increase in constructive motivations toward the perpetrator (p. 129).

Another definition is suggested by Worthington (2003):

... [forgiveness] as being of two types: one is decisional forgiveness that involves a change in a person's behavioral intentions (hence a change in motivation) toward a transgressor. The other is emotional forgiveness that is a replacement of negative, unforgiving emotions with positive, other-oriented emotions.

There are other definitions of forgiveness as well, but all definitions identify forgiveness as a conscious choice to let go of anger and resentment towards an offender (Smedes, 1997).

Contemplating these definitions might lead to two distinct possible responses: one is that the use of the term "forgiveness" in educational systems can be regarded as irrelevant, except of course in cases of specific conflicts among children, when one is trying to guide them to resolve their conflicts and forgive each other. The other is that tests can be conceptualized as "transgressors" in the educational system because they are likely to distresses and hurt children. That is due to the fact that like in any standardized assessment, the results usually shape a normal bell curve, which means that at least $33 \%$ of the learners are tagged as failures (Moreno, Maloney, \& Brown, 
2010). Such failure is an image that may be scorched in their feelings and memory for many years, sometimes even for life. In many cases students do succeed in tests and learn to conform to the system. However, the price may be that they will gradually lose understanding of who they are and confidence in their unique capabilities (Robinson, 2018); many of them have talents in areas that are considered of no importance to the system (i.e., dancing, cooking, juggling or car mechanics), and that are, in many cases, left undeveloped.

This circumstance poses a dilemma for teachers and educators. On the one hand, research shows that favorable teacher-student relationships stimulate students' learning and their sense of security (Wubbels, Brekelmans, Minhard, den Brok, \& van Tartwijk, 2016). On the other hand, teachers are required to test their students frequently, which, as empirical evidence suggests, causes distress and hampers students' motivation and well-being (Abeles \& Rubenstein, 2015). Moreover, teachers often develop caring and supportive relationships with their students, with whom they meet daily for one year, and sometimes for more than a year, and whom they get to know closely. That dynamic is in tension with the top-down instruction to test students, and the tension causes stress and hurt to many of the students, and leads them to perceive their teachers as agents of a transgressive system. In other words, teachers are caught between the demands forced upon them by educational policy makers and their students' emotional needs.

\section{FORGIVENESS IN EDUCATION}

The word "forgiveness" is used by people daily. Children are taught to use it as an apology every time they hurt someone or behave in an undesirable way. But while children are asked to be forgiving towards each other, they go to school, which they experience as a place where they are offended or hurt by their peers, their teachers and, often, their test scores. In most cases no one apologizes to them or even thinks that they should, because it is not part of school culture (Sacks, 1999). This absence of apologies has been severely criticized in light of the damage it inflicts on teachers and schools (Nichols et al., 2007; Dollinger, 2011; Sahlberg et al., 2017). The unforgiving nature of the system, and the denial of personal care to children that are hurt by the rigidity of tests are not consistent with what children themselves are told to do when they hurt others. This is not to say that teachers do not care about their students, but mostly, as Noddings (2005) asserted, in light of 
the demands made on them, "teachers 'care' in the sense that they conscientiously pursue certain goals for their students, and they often work hard at coercing students to achieve those goals." However, relating with care-in the sense of allowing children to make errors, and forgiving their mistakes again and again until they do things right - is hardly part of educators' discourse, nor are teachers trained to discuss it or to practice it (Willems, Lunenberg, \& Korthagen, 2005). The inherent contradiction mentioned above raises the need to reconsider and redefine the issue of forgiveness in an educational setting.

In this article, we suggest the following definition of the nature of forgiveness as a key value in educational contexts: forgiveness is part of the understanding that none of us are perfect human beings, and that each of us makes errors and mistakes that are crucial to our human cognitive and emotional development. All of us, children and adults, have unpredicted and surprising potential that needs to be discovered and developed (Philosophical Frameworks, 2015). This description of forgiveness suggests that we should provide children with the opportunity to make errors and to try again until they succeed in whatever they do, with no judgement, testing, or criticism but with sensitive guidance while they try. Our definition of "forgiveness" touches on the traditional definition of the term in that it trains teachers to let go of their disappointment with students' failures on tests and their slow progress.

\section{VALUES EDUCATION AND FORGIVENESS}

Values are considered to have fundamental importance in education (Bai1y, 2000; Halstead \& Taylor, 1996; Lickona, 1991; Osbeck et al., 2018; Thornberg \& Ogus, 2013). Educational systems invest considerable effort and money to plan and design values education and character building for students (Carr, 2006, 2009). For example, in Australia the Ministerial Council on Education, Employment, Training and Youth Affairs (MCEETYA) which represents all state and territory education ministers, issued a report saying

that education is as much about building character as it is about equipping students with specific skills; that values-based education can strengthen students' self-esteem, optimism and commitment to personal fulfilment; and help students exercise ethical judgment and social responsibility (see Lovat et al., 2009, in reference to DEST, 2003, p. 10). 
However, the inherent incongruity between, on the one hand, the aspiration to educate for values and to encourage students' high self-esteem and, on the other hand, the political-economic goal of every educational system in most countries to produce high academic achievements, is in itself a problematic message for students and for teachers, and it is hardly ever addressed. There is evidence that values education in schools creates a positive atmosphere and impacts students' diligence (Lovat et al., 2011). Nevertheless, forgiveness - in the sense of allowing students to err until they succeed, and eliminating the assessment of all students by standardized tests (one size fits all) - is not part of the educational conversation about values. In this article we draw on research that has found empirical evidence for the idea that forgiving mistakes people make generates surprisingly positive results (Worthington, 2006; Enright \& Fitzgibbons, 2015).

Aimed at creating such a conversation by asking experienced teachers what they think about forgiveness when relating to their work, our two research questions were:

1. How do high-school teachers perceive the concept of forgiveness in their work with students? and

2. Do they connect between forgiveness and the mechanism of testing and grading students?

\section{Method}

Participants. 31 high school teachers from one big high-school in a city located in northern Israel participated in the study. All of them had been teaching for over 6 years in the school, and some had as many as 28 year of experience in teaching. A minimum of 6 years in the school was needed in order to get a good enough perspective regarding their teaching. Their age ranged between 32-60, and most of them had school administrative functions besides teaching, such as head of the science department, educational counselor, or head of language studies. The student population of the school is diverse and includes both secular and religious Jewish students, as well as Druze students, all from middle class communities.

Research tools. To learn what teachers think about the idea of forgiveness in education, a qualitative research method was chosen. Teachers were interviewed and were asked to respond to 4 questions: 1. Do you perceive forgiveness to be an important trait in education; 2. Students may make mistakes in the academic domain and they may behave in a wrong way; in which type of case do you feel it is easier for you to forgive? 3. In your opinion, is 
there a connection between forgiveness and the mechanism of tests and scores in school? 4. What makes it difficult for you to forgive students?

Procedure. Only teachers with at least six years of seniority were chosen. Each of them was asked if he or she would be ready to partake in an interview about the subject of forgiveness in school. After agreeing to be interviewed, a time and place were scheduled for each (30 minute) interview. At the beginning of each interview, the description of forgiveness mentioned above, which was formulated for the current study, was presented to the teachers, along with a brief explanation of its unique meaning. The interviewer, who was herself a teacher at the school, and who was known to the interviewed teachers, asked their permission to record the interview. All of them agreed.

Content analysis. All interviews were transcribed, including pauses, and the interviewees attempts to correct some of their statements (Kowal \& O'Connel, 2014). A content analysis was then performed, following the steps suggested by Schreier (2014), i.e., selecting the material and creating code categories, defining the categories, revising and expanding the codes so that most of the data could be included. The data was read and reread so that a deeper penetration into teachers' statements could be achieved. The next step was to eliminate irrelevant data, and the result was 287 of the most meaningful statements of the participants which were taken into account (Roulston, 2011, 2014). Two judges first read the categories and their definitions on their own, and then they met to discuss the coding and the interpretations (Cornish, Gillespie, \& Zittoun, 2014). The results of the discussion were that two definitions of categories were changed, and one category was eliminated. Ultimately, the judges agreed with respect to $86 \%$ of the categories. It was also decided, following a practice engaged in by a number of qualitative researchers (Maxwell, 2010) to count all of the teachers' relevant statements so that when they were coded, it would be possible to trace the most salient categories, and the frequency of each category.

\section{Results}

Content analysis of the teachers' interviews yielded 10 categories. The coding was based on teachers' own words. The categories, their frequency and some examples of teachers' statements in each category are presented in Table 1. 
Table 1. Categories coded from the interviews, their frequency and some examples of teachers' statements in each category

\begin{tabular}{|c|c|c|}
\hline Category & Examples from teachers' statements & Frequency \\
\hline $\begin{array}{l}\text { Forgiveness is an } \\
\text { important value in life } \\
\text { and in education. } \\
\text { A teacher's forgiveness } \\
\text { serves as a role model } \\
\text { for students }\end{array}$ & $\begin{array}{l}\text { "... the instant in which I forgive, as an educator, } \\
\text { or as someone they [the students] trust, is a learning } \\
\text { moment [for a child], and it will penetrate... even } \\
\text { subconsciously." } \\
\text { "I think that we [teachers] are the compass; I show } \\
\text { them the way, serve as a role model... but eventually } \\
\text { they have to make their [own] choice..." } \\
\text { "I do not have the privilege of not forgiving... This is } \\
\text { not a choice for me; if you, as an adult, don't forgive, } \\
\text { how can you expect a child to forgive?" } \\
\text { "If we will not perceive forgiveness as a value of } \\
\text { major importance, we will not be able to allow } \\
\text { students the opportunity to correct their mistakes } \\
\text { again and again... only if we think of it } \\
\text { [of forgiveness] as a supreme value will we be able to } \\
\text { enable students to make mistakes until they get it } \\
\text { right." } \\
\text { "... not giving a student another opportunity to } \\
\text { correct can, later in his life, cause him to think that } \\
\text { there aren't second or third chances for him... so yes, } \\
\text { it [forgiveness] is a very important value in } \\
\text { education." }\end{array}$ & 35 \\
\hline $\begin{array}{l}\text { Forgiveness enables an } \\
\text { educational process and } \\
\text { provides an opportunity } \\
\text { for growth and success }\end{array}$ & $\begin{array}{l}\text { "... and how can a child bloom if he or she is not } \\
\text { given an opportunity again and again? We are here to } \\
\text { give them the opportunity to grow and blossom..." } \\
\text { "When you forgive, then there is a way to continue } \\
\text { ahead; if you don't, then that's... the end... no going } \\
\text { back to correct, and no continuation..." } \\
\text { "... I always ask myself how do I learn to forgive } \\
\text { a child so that we can both grow and develop... I think } \\
\text { that if this is missing [in our work] we become a... } \\
\text { we perform a cold, robotic alienated education, which } \\
\text { means that it is no longer education..." } \\
\text { "If we don't give forgiveness a place, an educational } \\
\text { process will be impossible. This is a kind of very high } \\
\text { human value that people must learn... some of us } \\
\text { need everything to be perfect, we educate for } \\
\text { achievements and it is hard not to wish to be perfect... } \\
\text { we do need to forgive... first of all ourselves, and to } \\
\text { recognize the fact that we are not perfect..." }\end{array}$ & 36 \\
\hline
\end{tabular}




\begin{tabular}{|c|c|c|}
\hline $\begin{array}{l}\text { It's easier to forgive in } \\
\text { the academic domain } \\
\text { and harder when } \\
\text { students misbehave }\end{array}$ & $\begin{array}{l}\text { "It's much harder to accept failures in the sphere of } \\
\text { wrong behavior than mistakes in learning a subject } \\
\text { matter." } \\
\text { "It's easier to forgive failures of knowledge and } \\
\text { learning and I find it more difficult to forgive } \\
\text { wrongdoing or behavior..." } \\
\text { "It is easier to forgive in the knowledge domain, you } \\
\text { can always correct, add, but when we speak about } \\
\text { behavior... it can hurt both the student and the } \\
\text { teacher... because wrong behavior can hurt..." } \\
\text { "Even when a student has difficulties learning a given } \\
\text { subject, it has no influence on my opinion about } \\
\text { him... I still see him as an intelligent kid who has } \\
\text { capabilities and skills in other subjects." }\end{array}$ & 38 \\
\hline $\begin{array}{l}\text { Forgiveness has } \\
\text { nothing to do with } \\
\text { repeated opportunities }\end{array}$ & $\begin{array}{l}\text { "If a student fails, he or she can get a second } \\
\text { opportunity. It has no connection to the issue of } \\
\text { forgiveness..." } \\
\text { "That connection you did between giving } \\
\text { opportunities to correct failures time and again and } \\
\text { between forgiveness is new to me. I never thought } \\
\text { about it. ... If you had asked me before your } \\
\text { introduction (i.e., the definitions of forgiveness in the } \\
\text { context of the current research) if forgiveness is } \\
\text { important, I might have said no... but [given] the } \\
\text { connection you drew... well, it seems important..." }\end{array}$ & 11 \\
\hline $\begin{array}{l}\text { Forgiving again and } \\
\text { again is not effective, } \\
\text { we need limits }\end{array}$ & $\begin{array}{l}\text { "There is a difference between a student who tries } \\
\text { very hard to succeed and someone who simply does } \\
\text { nothing. I know who makes a serious effort; only then } \\
\text { I will do anything to help..." } \\
\text { "We need to set boundaries... there is a point beyond } \\
\text { which we fall short of reaching our educational goal } \\
\text { and we do not teach the students to bear } \\
\text { responsibility for what they do." } \\
\text { "... some teachers call it giving another opportunity, } \\
\text { but in fact that means avoiding confrontation with the } \\
\text { student. We need to identify and set the right borders } \\
\text { for them..." } \\
\text { "A student sits in the classroom doing all kinds of } \\
\text { things that are not related to what he needs to study... } \\
\text { well, if he fails, he can do a late exam date, but that's } \\
\text { it. There are teachers who would not allow even that. } \\
\text { They say that the student had to study for the test } \\
\text { right from the first time..." }\end{array}$ & 45 \\
\hline
\end{tabular}




\begin{tabular}{|c|c|c|}
\hline $\begin{array}{l}\text { Teachers and students } \\
\text { have a shared } \\
\text { responsibility in the } \\
\text { educational process }\end{array}$ & $\begin{array}{l}\text { "If a student asks me for help, I will do anything I can } \\
\text { to help him, but [the request] has to come from him. } \\
\text { I don't see myself trying to persuade him... no... } \\
\text { and I don't think it's the right way... well, yes, we } \\
\text { need to create a pleasant atmosphere to make it } \\
\text { possible for them to come and ask questions, but they } \\
\text { need to learn to ask for help." } \\
\text { "I believe in the phrase 'we do not give you } \\
\text { concessions and we do not give up on you,' but also, } \\
\text { you should not give up on yourselves. It is a kind of } \\
\text { a triangle in which two thirds are our responsibility, } \\
\text { but one third is the students' responsibility..." }\end{array}$ & 37 \\
\hline $\begin{array}{l}\text { Students' failures with } \\
\text { regard to wrong } \\
\text { behavior have an effect } \\
\text { on me. Forgiveness } \\
\text { requires a mental and } \\
\text { emotional effort }\end{array}$ & $\begin{array}{l}\text { “... but when it [a student's wrong behavior] } \\
\text { happened the second time, I could not forgive... } \\
\text { he came to apologize but I feel that I can't forgive... } \\
\text { something very deep inside me was hurt... and } \\
\text { sometimes even I am entitled to not forgive..." } \\
\text { "When I find it hard to forgive, I struggle with } \\
\text { myself." } \\
\text { "Forgiving means that I, between me and myself, } \\
\text { open a new page with a student, but it's not always } \\
\text { easy..." } \\
\text { "... it is not possible to not forgive a student, even } \\
\text { when it is very hard... even if maybe in other places } \\
\text { [other than school] he would not be forgiven..." } \\
\text { "[forgiveness] is something to be acquired, it has to } \\
\text { do with training oneself to see others... you learn it, } \\
\text { you learn to forgive... in my first year [of teaching] } \\
\text { I had some crises... it did not show externally, but if } \\
\text { it had... It does not happen now. There is definitely } \\
\text { a learning process there." }\end{array}$ & 34 \\
\hline $\begin{array}{l}\text { There is a connection } \\
\text { between (practicing) } \\
\text { forgiveness } \\
\text { and tests }\end{array}$ & $\begin{array}{l}\text { "We have to follow the demands. I mean: testing, } \\
\text { paperwork, students' conduct etc. With all due } \\
\text { respect, these are the demands and there's not much } \\
\text { we can do about it." } \\
\text { "The idea of giving students a new opportunity each } \\
\text { time they fail is very limited because we work in an } \\
\text { unforgiving system. I thing that some of the teachers } \\
\text { became indifferent to the normal curve of scores } \\
\text { (i.e., that over } 30 \% \text { of students fail). It is hard for me } \\
\text { to accept it... Behind every failure is [someone who } \\
\text { is a] } 100 \% \text { human being..." } \\
\text { "The educational system is unforgiving and the more } \\
\text { it insists on achievement, the less is its } \\
\text { (and our) ability to forgive..." }\end{array}$ & 43 \\
\hline
\end{tabular}




\begin{tabular}{|c|c|c|}
\hline $\begin{array}{l}\text { A good way to forgive } \\
\text { is to find good things in } \\
\text { a child or to } \\
\text { understand his } \\
\text { hardships }\end{array}$ & $\begin{array}{l}\text { "I can see that some children fail not because they do } \\
\text { not wish to study but because they live in } \\
\text { unsupportive environments... they are emotionally } \\
\text { not available for learning. No one at home can sit and } \\
\text { help them or even make sure that they take a } \\
\text { shower..." } \\
\text { "It's not a matter of forgiving or not forgiving... } \\
\text { I simply accept the child as is and try not to judge his } \\
\text { behavior. I try to interpret and understand..." } \\
\text { "... I tried to put myself in his shoes. I even thought } \\
\text { of my own children... what would they do if they } \\
\text { were in his situation." } \\
\text { "Understanding and empathy are the building blocks } \\
\text { of the ability to forgive." }\end{array}$ & 32 \\
\hline $\begin{array}{l}\text { If teachers believe } \\
\text { in students despite their } \\
\text { errors, then } \\
\text { the students } \\
\text { can believe } \\
\text { in themselves }\end{array}$ & $\begin{array}{l}\text { "... when I forgive a student, it creates well-being } \\
\text { which enables him or her to go on and to not be } \\
\text { paralyzed by his or her failure." } \\
\text { "When I forgive a student, it enables him or her to } \\
\text { continue to be part of the classroom... They can go } \\
\text { on with what they have to do..." } \\
\text { "If you forgive a student and get closer to him or her, } \\
\text { they will fill safe... safe even to fail..." }\end{array}$ & 19 \\
\hline
\end{tabular}

The following figure demonstrates the frequency of teachers' statements in each category.

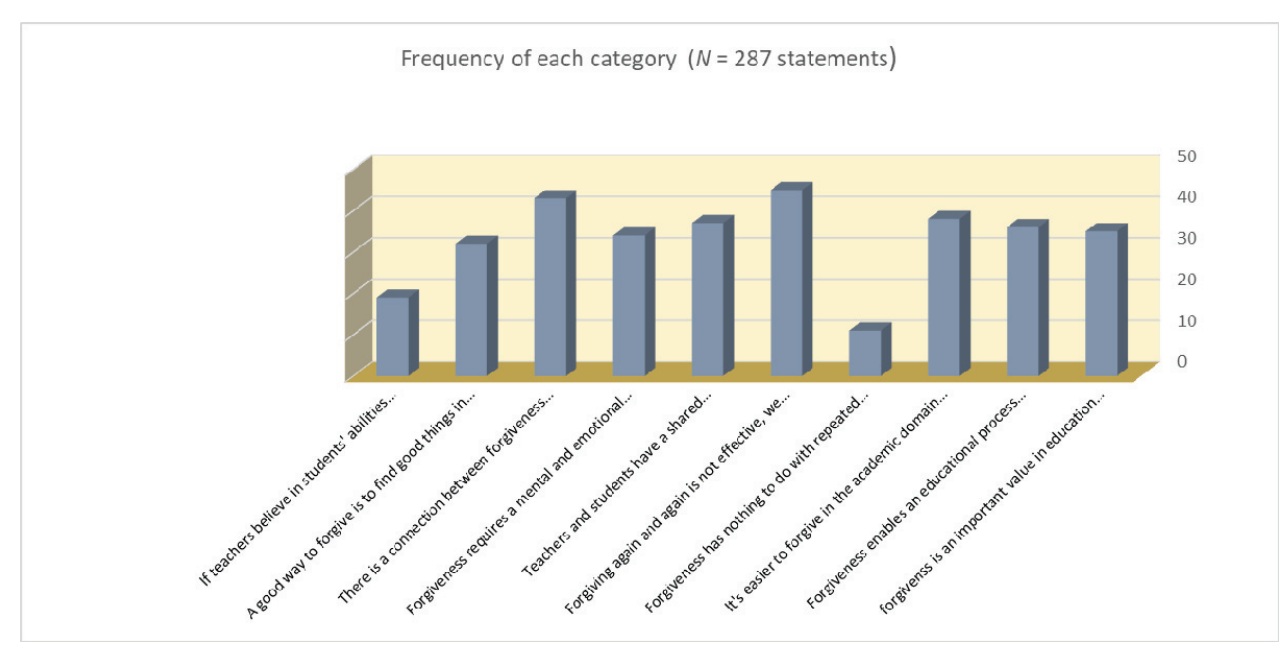

Figure 1. Frequency of teachers' statements in each category. 


\section{DISCUSSION}

When considering teachers' reactions to the interviews there were a few issues, some of them unexpected, that emerged, one of which was the resistance teachers expressed at the beginning of the interview. For example, teachers asked the interviewer to repeat the question or said that they were not sure they understood it. One of the teachers responded by saying "Well, it's a good question. I don't know what to say..." Most of the teachers resisted the definition that was presented to them, as one said "I think the use of this word [forgiveness] is not right," and another said "Wait, I am trying to connect... [between the word forgiveness and giving students enough opportunities until they succeed]." Also, it appears that the interview touched upon some sensitive points among many of them, which triggered stories from their lives and past experiences as students. The new and unfamiliar definition of forgiveness that was presented to the teachers (i.e., enabling students to make errors and mistakes again and again until they can succeed) made it difficult for some of them to clearly articulate what was on their minds. However, after crossing this hurdle, it was easier for the teachers to relate to the issue, and after studying their responses to the questions, they seem to have touched upon three major concerns: a. the value and the importance of forgiveness in education; $b$. apprehension about forgiving without limits, and the conviction that forgiving cannot be a one-way action; c. an understanding that forgiveness in the context of teaching is a learning process for both students and teachers, and d. understanding the damage of testing and grading students on one hand and failing to see the connection between forgiveness and testing on the other hand.

a. The value and importance of forgiveness in education. From categories 1,2 and 10 we can see that the teachers understand the idea of forgiveness, and that they even associated it with life generally, and not with education specifically, as one of the teachers said:

We know that forgiveness plays a very meaningful role in our lives, and we are, ultimately... In everything that relates to interpersonal relations, there are ups and downs, as well as clashes. If we'll approach things from a very rigid, inflexible position, and we won't understand... that the other side, even if it has done something that hurt us... If we won't be able to forgive, then actually we won't be able to work together. Ultimately, if we remain rigid, we won't be able to make progress in any context, neither as children nor as adults. Once we enable students to see that we forgive and that we move on, it serves as a personal example for them and they learn to do so as well. 
Another teacher said, about this issue:

I think that forgiveness is a very important value in interpersonal relationships, and of course in education as well. When you forgive, you give the other person the option to change the thing in which he or she erred, and to correct it. Forgiveness creates obligation: when you forgive a person, he or she is indebted to you, even if this occurs at an unconscious level, and relates to the concept of "reciprocity."

Other statements also attest to teachers' understanding what the educational system's purpose was supposed to be:

\begin{abstract}
An educational system is the ground on which students grow. ... Actually, it is here [in school] that they have the ground on which to make mistakes, to fall, but we ... our role is to give them a kind of safety net so that they can fall without getting smashed. Actually, forgiveness is one of our tools; it is an educational tool that we can use in order to lay out that safety net, and even if the student has slipped and fallen, which happens to all of us, here he has the space to do so, and we protect him.
\end{abstract}

The teacher's understanding here is that the education system should serve as a safety net for students, on which they are able to fall, to fail and to get up again, while they are protected throughout the process. This is consistent with the views held by a few of the researchers in the field (Lin, Enright, \& Klatt, 2011; Wubbels et al., 2016). The three categories dealing with this topic appeared 71 times in the teachers' statements.

b. Unlimited forgiveness can be harmful. This was the category that appeared most frequently in the teachers' statements $(N=45)$. It was expressed by the teachers in statements like

To forgive again and again and again ... when what's at issue is a behavioral failure involves an absence of defined boundaries, because [the student] immediately knows that "oh, they'll forgive me" and he can [misbehave] again and again ... No, [forgiveness] needs to be limited!

Another teacher says "If we give [students] an infinite [number], if we just give them chances and there'll be no limit, it will be meaningless, it will have no value. That's not educational." Unlimited forgiveness is a broad topic, which has mainly been studied in the field of interpersonal psychology (Luchies, Finkel, McNulty, \& Kumashiro, 2010; McCullough et al., 1998). One of the views is that unlimited forgiveness has a cost, and can even be harmful, as the dynamic it creates does not offer participants an accurate re- 
flection of reality (McNulty, 2011). It seems that based on their professional experience, the teachers point to "forgiveness," as defined in the present study, having a broader context that requires discussion, thought and a balanced view of forgiveness and of the varying results found among different students.

c. Forgiveness in the context of teaching is a learning process for both students and teachers. In this category, the teachers raised a few interesting points, among them the acknowledgement that repeated forgiving of students' mistakes and errors is a skill that one needs to develop, that one needs to practice. For example, one of the teachers said:

We need to detach ourselves from our emotional baggage, but this requires us to work on ourselves. It might be easier for emotional people than for rational people. Do I always succeed in doing it? No, I don't, but I try to be as free of personal considerations when I interact with a student who is asking to prove himself anew. Sometime a student repeats difficult behavior to the point of harming my own sanity, and then it's more difficult for me to give him more chances.

Another teacher said:

... And I slip up, it's clear that I slip up. I say things that I regret, and it isn't always possible to go back ... Maybe it's easier for the school psychologist, as that's her profession, she has learned to accept ... I need to work on it.

It's possible that the teachers' responses indicate a need for a type of professional training that they are currently not receiving, since traditionally, the emphasis in teacher training, especially for post-primary school teaching, is on disciplinary skills and on effective teaching methods, whereas emotional relations between teachers and students (emotional intelligence) are generally not part of such training (Gilar-Corbi et al., 2018). Although in recent years it seems that the topic has come to be perceived as important, and even essential for teachers (Dolev \& Leshem, 2017), there is still a considerable gap between the idea and its practice in schools.

d. Understanding the damage in testing and grading students on the one hand, and, on the other hand, failing to see the connection between forgiveness and testing:

Some of the teachers' responses reflect the dualism in which teachers work: on the one hand there is their professional need to be supportive of students and to help them succeed in their studies, each according to his or her ability, and on the other hand there are the norms involving tests, achievement and competition, which teachers are required to adhere to. The 
teachers expressed a dilemma concerning tests, that many researchers have studied (Heckman et al., 2014; Johnson, Johnson, Farenga, \& Ness, 2008; Nichols et al., 2007). The teachers' statements in the present study represent some of the emotional aspect involved in that dilemma, through the lens of their professional work. A number of the following statements attest to this:

... And when we [choose teaching] we should understand that we are going into a life-changing career, and understand that in every little thing that we do, we are models for imitation. To understand that hundreds of students look up to us, and that this can really change worlds. Every word we utter can really build or demolish worlds; this is very different from other professions. That is the true magic of this profession.

I think that the grading mechanisms are very rigid; they are very penalizing, because again, you are ultimately being measured ... your knowledge is being assessed and assigned a number. I can be super forgiving, but ultimately the score is written on a form.

Grades are a very cold mechanism. It's something that he (the student) is marked by and that stays with him. Indeed, the whole mechanism of grading students solely with numbers, without looking at additional factors and other skills they have is certainly ... it hurts to see a student who feels that he's received a score that doesn't reflect the amount of investment he's put into studying for the test, so yes, it always hurts me, and if he wants to correct it, I'm willing to give him the chance to correct it, but given the amount of work they have, and the amount of work I have, it isn't always possible...

I have a problem with the fact that some of us brand children according to scores, [with saying] "this child is 70 , that child is 90 , that other child is ..." I have a problem with that! I think that a child with a grade of 40 can be marvelous and full of values, with a rich world of content ... and here he has a grade of 40 in one subject or another ... a student shouldn't be seen ... [whether he is] a child, or an adult, as " 60, ," 40, ," "70."

These statements allow us to peek into the inner world of teachers, and to see the contradiction in which they live, even if they themselves don't see it as a contradiction. At the same time, there are teachers who succeed in balancing the contradiction within themselves by adopting a more pragmatic approach:

"I don't see any connection between the grading mechanisms and forgiveness."

"These mechanisms that we teachers are evaluated on are unforgiving towards us, and they encourage us, consciously or unconsciously, to be unforgiving towards others."

"[Students'] self-image nowadays, or at least their academic self-image, is constructed through the prism of grades. This is a mistake but there's nothing to be done about it." 
"I think that a uniform policy prevents opacity, prevents questions and dithering. On the other hand, order prevents flexibility."

The emotional dilemma that arises from these statements brings to light an aspect that is not often emphasized, which is the emotional burnout teachers experience. Although a great deal of research has been done on this topic (Bauer et al., 2006; Freudenberger, 1974; Golonka \& Marek, 2015; Maslach, Schaufeli, \& Leiter, 2001) not enough research has been done on the contradiction in which teachers live, and on its effects on their behavior and their professional perceptions.

In conclusion, the present research raises a number of points concerning the value of forgiveness as we have defined it here and as the teachers perceive it:

First, it appears that teachers do not conceptually draw a connection between forgiveness and their work at school. That connection was drawn only after discussion with, and clarification by, the interviewer, following which the teachers' emotional inner worlds with respect to forgiveness - and the complexity of their relations with students-became evident.

Second, the teachers are caught between, on the one hand, their feelings towards their students, and their desire to help all the students, and, on the other hand, the demands made on them from on high. The interviews showed that teachers live, to a large extent, with an internal tension, which, up until now, has not received appropriate attention.

The research's limitations: because this research is, with respect to this topic, pioneering, it teaches us that we should rigorously examine the interview questions and the way in which "forgiveness," as a value, is presented to teachers. It seems that the difficulty in this research stemmed from its having begun without there having been a conceptual infrastructure that was shared in common between the interviewer and the teachers; that factor should be given due consideration.

Suggestion for further research: what emerges from the interviews indicates a need for further research on this topic, especially in light of the fact that we are, today, living in the midst of a pandemic that has completely changed the world's educational systems. It seems that there is an immediate need to attend to the value of forgiveness, both with respect to students who are not meeting their friends and teachers (in person), and with respect to teachers, whose assessment of students, with whom they meet mainly in zoom distant learning, has acquired enormous importance. 


\section{REFERENCES}

Abeles, R., \& Rubenstein, G. (2015) Beyond measure: Rescuing an overscheduled, overtested, underestimated generation. New York: Simon \& Schuster.

BAILEY, R. (Ed.) (2000). Teaching values and citizenship across the curriculum (2nd ed.). New York: Routledge.

Bauer, J., Stamm, A., Virnich, K., Wissing, K., Udo Müller, U., Wirsching, M., \& SchaARSCHMIDT, U. (2006). Correlation between burnout syndrome and psychological and psychosomatic symptoms among teachers. International Arch Occupational and Environment Health, 79, 199-204. DOI 10.1007/s00420-005-0050-y.

BERLiner, D. (2011). Rational responses to high stakes testing: The case of curriculum narrowing and the harm that follows. Cambridge Journal of Education, 41(3), 287-302.

BERLINER, D. (2015). The many facets of PISA. Teacher College Record, 117(1), 1-20.

CARR, D. (2006). Professional and personal values and virtues in teaching. Oxford Review of Education, 32(2), 171-183.

CARR, D. (2009). Virtue, mixed emotions and moral ambivalence. Philosophy, 84(327), 31-46. Retrieved January 1, 2021, from http://www.jstor.org/stable/20533169.

Cornish, F., Gillespie, A., \& ZitToun, T. (2014). Collaborative analysis of qualitative data. In U. Flick (Ed.), The Sage handbook of qualitative data analysis (pp. 79-93). Thousand Oaks, CA: Sage Publication, Ltd.

Denham, S., Neal, K., Wilson, B., Pickering, S., \& Boyatzis, C. (2005.) Emotional development and forgiveness in children: Emerging evidence. In E. L. Worthington, Jr (Ed.), Handbook of forgiveness (pp. 127-142). New York: Brunner-Routledge.

Dieter-MEYeR, H. (2014). The OECD as pivot of the emerging global education accountability regime: How accountable are the accountants? Teacher College Record, 116(9), 1-20.

Dolev, N., \& LeShem, S. (2017). Developing emotional intelligence competence among teachers. Teacher Development, 21(1), 21-39.

Dollinger, S. J. (2011). "Standardized minds" or individuality? Admissions tests and creativity revisited. Psychology of Aesthetics, Creativity, and the Arts, 5(4), 329-341. https://doi.org/10. 1037/a0023659

EnRight, R., \& Fitzgibbons, R. P. (2015). Forgiveness education. In Forgiveness Therapy: An empirical guide for resolving anger and restoring hope (pp. 233-250). Washington, DC: American Psychological Association.

Etherington, M. (2013). Values education: Why the teaching of values in schools is necessary, but not sufficient. Journal of Research on Christian Education, 22(2), 189-210. DOI: $10.1080 / 10656219.2013 .808973$

Freudenberger, H. J. (1974). Staff burnout. Journal of Social Issues, 30(1), 159-165.

Gilar-Corbi, R., Pozo-Rico, T., Pertegal-Felices, M., et Al. (2018) Emotional intelligence training intervention among trainee teachers: A quasi-experimental study. Psicologia: Reflexão e Crítica. 31, 33. https://doi.org/10.1186/s41155-018-0112-1.

GolonkA, K., \& MAREK, T. (2015). Job burnout and engagement among teachers: Worklife areas and personality traits as predictors of relationships with work. International Journal of Occupational Medicine and Environmental Health, 28(1), 102-119.

HAlsteAd, M., \& TAYlor, M. (1996). Values in education and education in values. LondonWashington: The Falmer Press. 
HaRgreaves, A. (2020). Large-scale assessments and their effects: The case of mid-stakes tests in Ontario. Journal of Educational Change, 21, 393-420.

Heckman, J., Humphries, E., \& Kauts, T. (Eds.) (2014). The myth of achievement tests: The GED and the role of character in American life. Chicago: University of Chicago Press.

Johnson, D., Johnson, B., FArenga, S., \& Ness, D. (2008). Stop high-stakes testing: An appeal to America's conscience. Lanham, MD: Rowman and Littlefield Publishers, Inc.

JONES, B. (2007). The unintended outcomes of high-stakes testing. Journal of Applied School Psychology, 23(2), 65-86.

KowAL, S., \& O'CONNEL, D. (2014). Transcriptions as a crucial step of data analysis. In U. Flick (Ed.), The Sage handbook of qualitative data analysis (pp. 64-79). Thousand Oaks, CA: Sage Publication, Ltd.

LicKONA, T. (1991) Educating for character: How our schools can teach respect and responsibility. New York: Bantam Books.

Lin, W.-N., EnRIGHT, R., \& KLATT, J. (2011). Forgiveness as character education for children and adolescents. Journal of Moral Education, 40(2), 237-253.

Lovat, T., Clement, N., Dally, K., \& Toomey, R. (2011). The impact of values education on school ambience and academic diligence. International Journal of Educational Research, 50(3), 166-170.

Lovat, T., Toomey, R., Dally, K., \& Clement, N. (2009). Project to test and measure the impact of values education on student effects and school ambience. Report for the Australian Government Department of Education, Employment and Work place relations. (DEEWR) by The University of Newcastle, Australia. Canberra: DEEWR.

Luchies, L., Finkel, E., McNulty, J., \& Kumashiro, M. (2010). The doormat effect: When forgiving erodes self-respect and self-concept clarity. Journal of Personality and Social Psychology, 98, 734-749.

Madaus, G., \& Russell, M. (2017). Paradoxes of high-stakes testing. Journal of Education, 190(1-2), 21-30. DOI:10.1177/0022057410190001-205

Maslach, C., Schaufeli, W., \& Leiter, M. (2001). Job burnout. Annual Review of Psychology, 52, 397-422. https://doi.org/10.1146/annurev.psych.52.1.397.

MAXWELL, J. (2010). Using numbers in qualitative research. Qualitative Inquiry, 16(6), 475-482.

McCullough, M. E., Rachal, K. C., Sandage, S. J., Worthington, E. L., JR., Brown, S. W., \& Hight, T. L. (1998). Interpersonal forgiving in close relationships: II. Theoretical elaboration and measurement. Journal of Personality and Social Psychology, 75(6), 1586-1603. https://doi.org/10.1037/0022-3514.75.6.1586.

MCNulty, J. (2011). The dark side of forgiveness: The tendency to forgive predicts continued psychological and physical aggression in marriage. Personality and Social Psychology Bulletin, 37 (6), 770-783. DOI: 10.1177/0146167211407077.

MCNulty, J. (2020) Highlighting the dark side of forgiveness and the need for a contextual approach. In E. WORTHINGTON, JR., \& N. WADE (Eds.), Handbook of forgiveness (2nd ed.) (pp. 33-42). New York: Routledge.

Moreno, A. J., Maloney, V. R., \& Brown, K. L. (2010). The case against testing young children to evaluate teacher effectiveness: A position statement from the Marsico Institute for Early Learning and Literacy. Issue Brief, No. 4, University of Denver.

Nichols, S., Berliner, D., \& Noddings, N. (2007). Collateral damage: How high-stakes testing corrupts America's schools. Boston: Harvard Education Press. 
NodDings, N. (2005). 'Caring in education'. The Encyclopedia of Pedagogy and Informal Education. Retrieved December 29, 2020 from: https://infed.org/mobi/caring-in-education/

Osbeck, C., Franck, O., Lilja, A., \& Sporre, K. (2018). Possible competences to be aimed at in ethics education: Ethical competences highlighted in educational research journals. Journal of Beliefs \& Values, 39(2), 195-208. https://doi.org/10.1080/13617672.2018.1450807.

RAvitch, D. (2016). The death and life of the great American school system: How testing and choice are undermining education. New York: Basic Books.

RoBInson, K. (2018). Creative schools: The grassroots revolution that's transforming education. New York: Penguin Books.

RothSteIN, R. (2008). The corruption of school accountability. School Administrator, 65(6), 14-15.

Roulston, K. (2011). Dealing with challenges in doing interview research. International Journal of Qualitative Methods, 10(4), 348-366.

Roulston, K. (2014). Analyzing interviews. In U. Flick (Ed.), The Sage handbook of qualitative data analysis (pp. 297-313). London: Sage Publication, Inc.

SACKS, P. (1999). Standardized minds: The high price of America's testing culture and what we can do to change it. Cambridge, MA: Perseus Books.

Sahlberg, P., Hasak, J., Rodriguez, V., \& Associates (2017). Hard questions on global educational change. New York: Teacher College Press.

SchreIER, M. (2014). Qualitative content analysis. In U. Flick (Ed.), The Sage handbook of qualitative data analysis (pp. 170-184). London: Sage Publication, Inc.

SMEDES, L. (1997). The art of forgiving. New York: Random House, Inc.

Stone, D. (2016). Qualitative analysis as narrative. In M. BEVIR, \& R. RHODEs (Eds.), Routledge handbook of interpretive political science (pp. 157-170). Milton Park: Routledge.

The seven pillars of forgiveness (1977). Philosophical Frameworks \& Feminenza International Based on "The Pathways of Forgiveness."

ThORnBerG, R., \& OĞUZ, E. (2013). Teachers' views on values education: A qualitative study in Sweden and Turkey. International Journal of Educational Research, 59(1), 49-56. http:// dx.doi.org/10.1016/j.ijer.2013.03.005.

Toussaint, L., \& WeBB, J. (2005). Theoretical and empirical connections between forgiveness, mental health, and well-being. In E. Worthington (Ed.), Handbook of forgiveness (pp. 349-362). New York: Routledge.

Willemse, M., Lunenberg, M., \& Korthagen, F. (2005). Values in education: A challenge for teacher educators. Teaching and Teacher Education, 21(2), 205-217.

Worthington, E. (2003). Forgiving and reconciling: Bridges to wholeness and hope. Downers Grove, IL: InterVarsity Press.

Worthington, E. (2006). Forgiveness and reconciliation: Theory and application. New York: Routledge.

Wubbels, T., Brekelmans, J. M. G., Minhard, T., Brok, Den, P., \& TartwiJk, Van, J. (2016). Teacher - student relationships and student achievement. In K. Wentzel, \& G. RAMANI (Eds.), Handbook of social influences in school contexts: Social-emotional, motivation, and cognitive outcomes (pp. 127-142). New York: Routledge. 
THE VALUE OF FORGIVENESS IN THE EYES OF HIGH-SCHOOL TEACHERS: DO THEY PERCEIVE IT AS RELATED TO TESTING AND GRADING STUDENTS?

\author{
SUMMARY
}

While forgiveness is considered an important value in life, the assessment of students through standardized tests is an unforgiving system within the educational setting. How do teachers perceive the connection between testing and forgiveness? The purpose of this study was to investigate this question. Thirty-one high school teachers were asked to respond to four questions, after being presented with a specific definition of forgiveness, suggesting that forgiveness means allowing people, and students, to make mistakes without judgment until they start doing things right. Teachers' responses were recorded, transcribed and analyzed. The content analysis yielded ten categories, some of which indicate that there is a tension between a) teachers' feelings toward their students and their wish to support and help them, and b) the formal top-down demands of the educational system. Teachers also pointed to the importance of there being limits to forgiving students' wrongdoing.

Keywords: forgiveness in education; standardized tests.

\title{
ROLA PRZEBACZENIA WEDŁUG NAUCZYCIELI SZKÓŁ ŚREDNICH - CZY UWAŻAJA, ŻE TESTOWANIE I OCENA UCZNIÓW WIĄŻĄ SIĘ Z PRZEBACZENIEM?
}

\section{STRESZCZENIE}

Podczas gdy przebaczanie uznaje się za istotną wartość, ocena uczniów prowadzona z użyciem standardowych metod testowania jest rozwiązaniem bezlitosnym. Celem tego opracowania było zbadanie kwestii, jak nauczyciele postrzegają związek między testowaniem a przebaczeniem? Trzydziestu jeden nauczycieli szkół średnich poproszono o odpowiedzi na cztery pytania, po przedstawieniu im konkretnej definicji przebaczenia, sugerującej, że przebaczenie oznacza pozwolenie ludziom i uczniom na popełnianie błędów bez osądzania, dopóki nie zaczną robić tego, co należy. Odpowiedzi respondentów nagrano, przepisano i przeanalizowano. Po przeanalizowaniu zawartości uzyskano dziesięć kategorii. Niektóre z nich wskazują, że istnieje napięcie pomiędzy (a) uczuciami nauczycieli wobec uczniów i ich chęcią wspierania i pomagania im, a (b) formalnymi, odgórnymi wymaganiami systemu szkolnictwa. Badani nauczyciele wskazywali również na rolę istnienia granic wybaczania uczniom ich przewinień.

Słowa kluczowe: przebaczenie w edukacji; testy standaryzowane. 